\title{
THE EFFECT OF SOCIO-ECONOMIC VARIABLES ON PUBLIC SECTOR PERFORMANCE: AN EMPIRICAL ANALYSIS ON PUBLIC EXPENDITURE IN TURKEY
}

\author{
SOSYO-EKONOMİK DEĞİŞKENLERİN KAMU SEKTÖR \\ PERFORMANSINA ETKİSI: TÜRKIYY'DE KAMU HARCAMALARI \\ ÜZERINE AMPİRIK BİR ANALİZ
}

\author{
Nagihan BİRINCI $\dot{I}^{*}$ \\ Osman Murat TELATAR ${ }^{* *}$ (D)
}

\begin{abstract}
Public sector performance is regarded as the impact of government activities on certain key economic and social indicators, that is, the outcome of public sector activities. In this respect, the share of public expenditures, which is considered as one of the most important indicators of the size of the public sector, in the gross domestic product is also considered as a powerful tool in terms of revealing the public sector performance. There are many studies in the literature examining the effect of public expenditures on socioeconomic variables. In this study, different from other studies in the literature, the effects of socio-economic variables on public expenditures were investigated. Thus, it is aimed to determine the effects of socioeconomic variables on public performance through public expenditures. For this purpose, the effects of the net public debt stock, the human development index, and the unemployment rate on public expenditure were analyzed by cointegration tests for the 1990-2018 period in Turkey. Empirical results obtained reveal that there is a long run relationship between variables. Accordingly, increases in net public debt stock and human development index increase public expenditures, while increases in the unemployment rate create a decrease in public expenditures.
\end{abstract}

Keywords: Public Sector Performance, Public Expenditure, Cointegration Tests

JEL Classification: H11, H53, C22

Özet

Kamu sektör performansı, devlet faaliyetlerinin belirli temel ekonomik ve sosyal göstergeler üzerindeki etkisi, yani kamu kesimi faaliyetlerinin çıktısı olarak kabul edilmektedir. Bu doğrultuda kamu sektörü büyüklüğünün en önemli göstergelerinden biri olarak kabul edilen kamu harcamalarının gayrisafi yurtiçi hasıla içerisindeki payı aynı zamanda kamu sektörü performansını ortaya koyma açısından da güçlü bir

* $\quad$ Asst. Prof. Dr., Karadeniz Technical University, Department of Public Finance, Ortahisar, Trabzon 61080, E-Mail: nbirinci@ktu.edu.tr

** Asst. Prof. Dr., Karadeniz Technical University, Department of Economics, Ortahisar, Trabzon 61080, E-Mail: omtelatar@ktu.edu.tr 
araç olarak kabul edilmektedir. Literatürde kamu harcamalarının sosyo-ekonomik değişkenler üzerindeki etkisini inceleyen çok sayıda çalışma bulunmaktadır. Bu çalışmada ise literatürdeki diğer çalışmalardan farklı olarak, sosyo-ekonomik değişkenlerin kamu harcamaları üzerindeki etkileri araştırılmıştır. Böylece söz konusu sosyo-ekonomik değişkenlerin kamu performansına etkilerinin, kamu harcamaların üzerinden tespit edilmesi amaçlanmıştır. Bu amaçla Türkiye’de kamu borçlanması, insani gelişim endeksi ve işsizlik oranı değişkenlerinin kamu harcamaları üzerindeki etkileri 1990-2018 dönemi için eş bütünleşme testleri ile analiz edilmiştir. Elde edilen ampirik sonuçlara göre değişkenler arasında uzun dönem ilişkisi bulunmaktadır. Buna göre, net kamu borç stoku ve insani gelişim endeksindeki artışlar kamu harcamalarını artırırken, işsizlik oranındaki artışlar kamu harcamalarında azalmaya yol açmaktadır.

Anahtar Kelimeler: Kamu Sektör Performansı, Kamu Harcamaları, Eşbütünleşme Testleri JEL Sinıflandırmasi: H11, H53, C22

\section{Introduction}

Nowadays, globalization and advances in information and communication technologies have brought about some transformations and changes in the field of management as well as in many other areas. Besides the private sector, the public sector was also affected by these transformations and changes. As a result of the failure of some concepts, approaches and practices from the past to adapt to the conditions of the day, a new public management approach has been adopted to provide faster and more efficient service delivery in the public sector. Together with this new approach, the concept of performance has gained importance in the public sector. Thus, the benefits and results of the transaction were taken as the main factor and the increase in the public expenditures over time increased the importance of the concept of performance towards the efficient use of public resources.

As it is known, the main function of the state is to produce public goods and services. In order to make the public expenditure required for this, it must increase the tax and similar income sources. From past to present, how much governments spend and how they to ensure efficiency while spending is constantly being discussed. Public sector performance is important both in the decisionmaking process of policy makers and in obtaining the highest benefit with lower public expenditure. For this reason, today many governments give more importance and spend time to the performance evaluation in public sector than ever before. The aim is to increase public sector performance to private sector performance level. However, when compared with the private sector, the efficiency and performance measurement in the public sector is quite difficult. The main reason for this is the difference between the goods and services produced by the public sector and the private sector.

Public sector performance, which implies that government activities have a significant effect on some basic economic and social indicators, is defined in the way that the result of public sector activities. As a result of the increasing share of public sector in the economy, the issue of performance has also gained importance in the public sector. The widely used indicator for measuring the size of the public sector is the ratio of total public expenditures to gross domestic product. This indicator is accepted as an indicator of the economic activities of the state and is also used to evaluate the public sector performance. 
In the literature, generally, the effects of public expenditures on socio-economic variables such as total education expenditures, total health expenditures, unemployment rate, and public borrowing, etc. have been investigated. In most of these studies, as public expenditures increased, the socioeconomic variables improved was concluded that. In this study, unlike other studies in the literature, the effect of socio-economic variables on public expenditures was investigated. On the other hand, one of the most important indicators of the size of the public sector is the share of public expenditures in the GDP. Thus, the study tried to analyze the effects of different socio-economic factors on public performance through public expenditures.

\section{Public Expenditure and the Size of the Public Sector}

Since the first day of its existence, what kind of tasks the state will undertake and what its limits are constantly being discussed. The main factor driving these discussions was the economic, social and political structures of the countries in general. In the pre-1929 period, when liberal understanding prevailed, the state was imposed limited duties and responsibilities with the preservations of public order, and after the Great World Depression of 1929, the state was assigned more duties and responsibilities and the share of public expenditures in total expenditures increased. Therefore, the share of the public sector in total economy has varied over time depending on the economic, social and political structures of the countries.

Especially since the second half of the 20th century, there have been significant developments in the economies of the country. Most countries became independent from colonial rule and soon after, the pursuit of development planning became the main topic for many states. Traditional budgeting and expenditure management were considered to be inadequate. As a result of this, development or capital budgets were prepared and supporting institutions such as planning ministries or commissions were established. Large investments were undertaken, many public enterprises were established and as a result of all these, the public sector grew very rapidly. The increase in the functions of the state and the characteristics of the welfare state steadily increased spending pressures. Therefore, the share of total public expenditures in GDP, which is considered as the most basic indicator of the size of the public sector, also increased steadily ${ }^{1}$. The rapid growth of the public sector brought about the increase in public expenditures, but the increase in public revenues was insufficient in response to the increase in expenditure.

Total public expenditure as percentage of gross domestic product (i.e., the size of public sector) in Turkey over the period 1990-2018 can be seen at Figure 1.

1 Premchand, A. (1996). Issues and New Directions in Public Expenditure Management, IMF Working Paper, 123 , p.6. 
Figure 1: Total Public Expenditure as \% of GDP in Turkey (1990-2018)

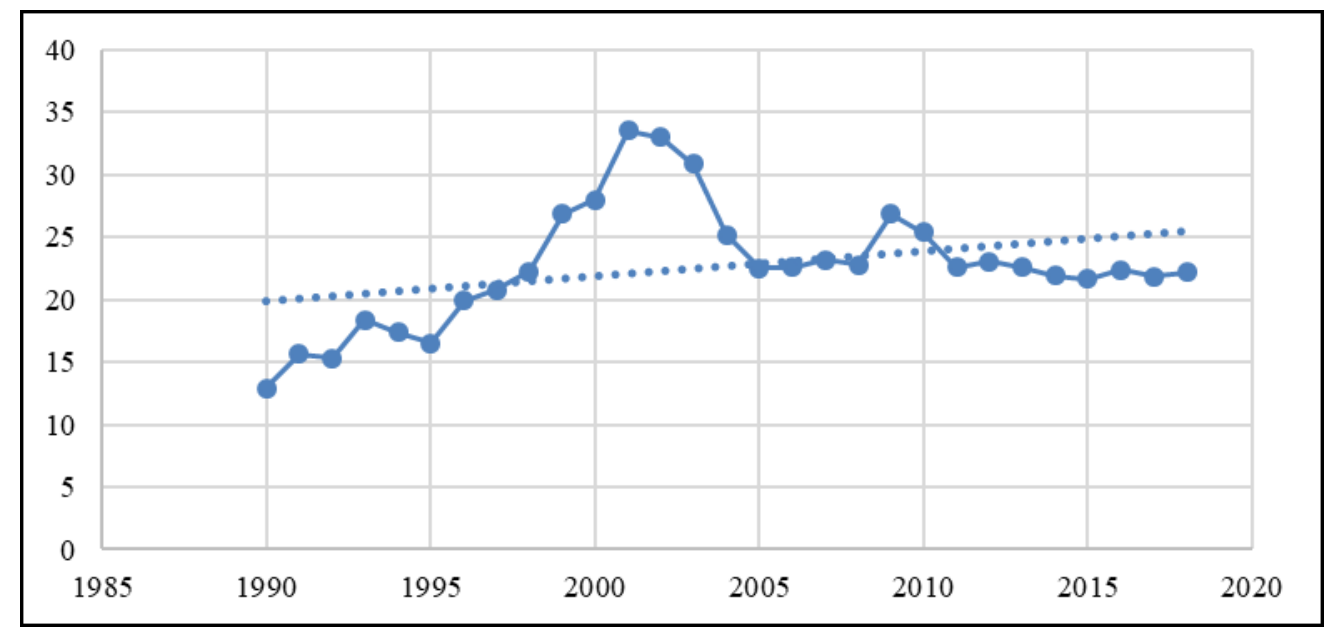

Source: Republic of Turkey Ministry of Treasury and Finance (1924-2018 Budget Revenues, Expenditures, Balance, https://www.hmb.gov.tr/bumko-butce-buyuklukleri-ve-butce-gerceklesmeleri).

It seems that the ratio of total public expenditure to gross domestic product in Turkey increased steadily since 1990. Especially from 1995 to 2001, the ratio of public expenditures to gross domestic product increased rapidly and reached its highest level in 2001. Although the ratio decreased from 2001 to 2005, it maintained its stability afterwards. As a result, the size of the public sector increased in the 1990-2018 period.

Governments provide their citizens with a range of goods and services to achieve various economic and social goals. In other words, governments intervene in the economy through public expenditures. However, the determination of the effectiveness of these goods and services is important not only to reveal the size of the state or to discuss the possible role of the private sector in the economy, but also to macroeconomic stability and economic growth ${ }^{2}$.

Public expenditures draw great attention from both governments and taxpayers due to its impact on economic growth in general. On the other hand, economic theory accepts public expenditures as the basic element of economic growth ${ }^{3}$. Indeed, Lucas ${ }^{4}$ argues that public education expenditures contribute to economic growth by increasing the level of human capital. Zagler and Dürnecker ${ }^{5}$ argue that fiscal policy tools such as infrastructure, public education, health, research and development expenditures have a long-term impact on the national economy. However, recent discussions

2 Gupta, S., Verhoeven, M. (2001). The Efficiency of Government Expenditure Experiences from Africa, Journal of Policy Modeling, 23, p.433-434.

3 Chan, S., Karim, M. Z. A. (2012). Public Spending Efficiency and Political and Economic Factors: Evidence from Selected East Asian Countries, Economic Annals, LVII, 193, p.8.

4 Lucas, R. E. (1988). On the Mechanics of Economic Development, Journal of Monetary Economics, 22 , p. 27.

5 Zagler, M., Dürnecker, G. (2003). Fiscal Policy and Economic Growth”, Journal of Economic Survey, 17, p.398. 
about the government and its role in the economy have shifted towards an empirical analysis of the effectiveness and efficiency of public sector activities ${ }^{6}$.

Public benefit is important for human life and quality of life. These social needs are met by the public sector and the private sector is not interested in these needs due to the lack of economic benefits. Public services such as national defense, maintaining the public order, disaster prevention and control cannot be provided by the private sector. Because these goods and services aren't goods and services that can make a profit. Therefore, the provision of these goods and services by the public sector emerges as a requirement ${ }^{7}$. However, effective allocation of scarce resources is important for both the private and public sectors.

In recent years, the phenomenon of globalization has increased public pressure on the efficient allocation of resources by creating a more mobile environment for capital flows. The effectiveness of public expenditures is key to the economic success of a country. Therefore, governments should implement a more transparent public expenditure policy ${ }^{8}$. The optimal size of public expenditure is difficult to address both empirically and theoretically. In practice, however, policy makers have to determine the level of public expenditure to maximize social welfare ${ }^{9}$.

\section{Efficiency and Performance in the Public Sector}

In all countries, the share of the public sector and the private sector in the total economy vary by periods. The welfare state understanding, which has gained more importance in recent years, contributes greatly to this difference. As a result of this understanding, public sector economy has an important share in the total economy. The main function of the public sector is to increase social welfare. For this, it must earn income and spend. However, because it directly affects social welfare, what is important here is the effectiveness of public services provided by the state.

\subsection{Efficiency in Public Sector}

The concept of efficiency is seen as the basic element in public expenditures and taxation studies ${ }^{10}$ and it is defined as the measure of the amount of output produced per input in general ${ }^{11}$. In other words, efficiency is provided by the relationship between output and inputs.

6 Chan and Karim, 2018, p.8.

7 Mihaiu, D. M. et al. (2010). Efficiency, Effectiveness and Performance of the Public Sector, Romanian Journal of Economic Forecasting, 4, p.134-135.

8 Afonso, A. et al. (2006). Public Sector Efficiency: Evidence for New EU Member States and Emerging Markets, ECB Working Paper, 581, p.5.

9 Afonso, A. et al. (2013). Public Sector Efficiency: Evidence for Latin America, Inter-American Development Bank, Discussion Paper, 279, p.3.

10 Zugravu, B. G., Sava, A. Ş. (2012). Recent Changes in Public Sector Efficiency in Romania: Determinants and Implications, Elsevier, Procedia-Social and Behavioral Sciences, 58, p.424.

11 Boyle, R. (2006). Measuring Public Sector Productivity: Lesson from International Experience, CPMR Discussion Paper, 35, p.4. 
The effectiveness of public expenditure, which represents the size of public sector economy, is defined as the ability of the government to maximize economic activities at a certain level of expenditure or the ability to minimize expenditure at a certain level of economic activity. Therefore, the effectiveness of public expenditure can be used as an indicator to evaluate the effectiveness of public policy implementations on management, economic stability, income distribution, health and education. It is important for government to spend the income collected from taxpayers effectively because of their responsibilities to them. The main problem of the economy is related to the efficient use of scarce resources. Accordingly, the concept of effectiveness provides an assessment of the resource allocation of a country in realizing economic growth ${ }^{12}$.

When it comes to efficiency and often compared with the private sector, the public sector is considered inefficient. But this statement needs to be thought carefully. Because, in order to evaluate efficiency between the two sectors, these sectors should be fully comparable. However, even with a very simple analysis, it can be demonstrated that the two sectors cannot be substituted for each other. First of all, the aims of the public and private sectors are different. While the private sector aims to make a profit, the public sector focuses on social benefit ${ }^{13}$. On the other hand, while it is very easy to define and measure inputs and outputs in the private sector, it is very difficult in the public sector.

Analyzing public sector effectiveness and making an international efficiency comparison is not easy because of complexity of the measurement, the nature of the data, and the different definition of public sector in different countries. In addition, other difficulties in measuring and comparing public sector efficiency are the lack of a single theoretical approach to ensure correct and clear determination of the fields of activity of the state, differences in size, structure and scope between public sectors, differences in political structure, demographic and geographical characteristics ${ }^{14}$.

Traditionally, when evaluating efficiency in government activities, taxes are used as the main input of government activities and expenditures are used as outputs. Those who deal with the issue in terms of macroeconomics considered input as public expenditures and output as growth rate in per capita income. However, these kinds of approaches are insufficient to explain how much the state activities contribute to social welfare ${ }^{15}$. Recently, with the developing new management approach, the effects of expenditures are tried to be evaluated by considering the results. In short, with the new approach, there is a shift from input-oriented structure to result-oriented structure in state activities ${ }^{16}$.

\subsection{Public Sector Performance}

In order to fulfill the functions undertaken by the state, i) it must collect the resources from the economy in an adequate and appropriate way, and ii) allocate and use these resources efficiently and

12 Chan and Karim, 2018, p.8.

13 Mihaiu et al., 2010, p.133.

14 Lovre, I. et al. (2017). Analysis of Public Sector Efficiency in Developed Countries, Economic Analysis, 50(1-2), p.39.

15 Güran, M. C., Cingi, S. (2002). Devletin Ekonomik Müdahalelerinin Etkinliği, Akdeniz İ.İ.B.F. Dergisi, 3, s.58.

16 Sakal, M., Şahin, E. A. (2008). Kamu Kurumlarında Performans Ölçümü ve Sayıştay Denetimi İlişkisi: Türkiye’deki Düzenlemeler Bakımından Bir Değerlendirme, Sayıștay Dergisi, 68, s.4. 
effectively ${ }^{17}$. Performance evaluation is especially important for the effective and efficient allocation and use of resources. Accordingly, the purpose of the Public Financial Management and Control Law No. 5018, which was published in the Official Gazette on 24.12.2003 and fully enacted on 01.01.2006 in Turkey, is to ensure the economic, effective and efficient use of public resources in the context of the principles of accountability and financial transparency ${ }^{18}$. Therefore, this law has adopted a management approach based on output/results. In order to achieve this, performance measurement appears to be a must in the public sector.

It is difficult for theorists and practitioners to define the concept of performance in the public sector. The main difficulty here arises from the complexity of the public sector, which has functions such as public policy development, implementation and service provision. Since there is no economic criterion based on concrete data reflecting the profit obtained by a commercial organization in the public sector, it is difficult to define and measure performance ${ }^{19}$. However, governments need to improve their citizens' living standards by providing access to basic services, living and working in peace and security. Excessive bureaucracy, red tape, over regulation, corruption, fraud in dealing with public contracts, lack of transparency, and the political dependence of the judicial system impose significant economic costs on enterprises and slow the process of economic development ${ }^{20}$. Citizens demand greater accountability and transparency from the government, so performance evaluation is a necessity ${ }^{21}$. In addition, demographic characteristics of countries differentiate demand structure and expectations and priorities of public sector vary from country to country. Therefore, despite the increasing demand for public sector services, the current financial constraints mean that many public institutions should these services with less resources. Accordingly, performance evaluation becomes a necessity again. As a matter of fact, effective evaluation of performance is very important in terms of creating a sustainable and stable public finance and creating confidence that public revenues are used effectively ${ }^{22}$.

The main objective of performance evaluation is to increase the quality of public goods and services ${ }^{23}$. The aim of increasing public sector performance is to reduce the tax burden, increase trust in the government and ensure efficiency in general. In order to ensure transparency of public decisions and the use of public funds, and to improve performance, performance management has been initiated in many public institutions. However, in practice, performance measurement is confronted with many

17 Allen, R., Tommasi, D. (2001). Managing Public Expenditure: A Reference Book for Transition Countries, http://www1. worldbank.org/publicsector/pe/oecdpemhandbook.pdf, (Accessed On: 05.07.2019), p.19.

185018 Sayılı Kamu Mali Yönetimi ve Kontrol Kanunu (24.12.2003 tarih, 25326 sayılı T.C. Resmî Gazete).

19 Leoveanu, A. (2016). Performance Evaluation Systems in the Public Sector, Curentul Juridic, p.26.

20 Schwab, K. (2013). Global Competitiveness Report 2013-2014. World Economic Forum, http://www3.weforum.org/ docs/WEF_GlobalCompetitivenessReport_2013-14.pdf (Accessed On: 05.07.2019), p.5.

21 Moreno-Enguix, M. R., Lorente Bayona, L. V. (2017). Factors Affecting Public Expenditure Efficiency in Developed Countries, Politics \& Policy, p.107.

22 CIMA (2011). Public Sector Performance: A Global Perspective, https://www.cimaglobal.com/ Documents/Thought_ leadership_docs/NHS-public-sector/public_sector_report_web_oct_2011.pdf (Accessed On: 07.05.2019)

23 Yenice, E. (2006). Kamu Kesiminde Performans Ölçümü ve Bütçe İlişkisi, Sayıştay Dergisi, 61, s.58. 
obstacles in terms of defining performance in public sector, identifying appropriate performance indicators, and implementing a performance management system ${ }^{24}$.

In many developed countries, total public expenditure is over $40 \%$ of GDP. However, the main questions to be asked whether governments are effective in allocating expenditures and whether public authorities can manage public resources more effectively and efficiently ${ }^{25}$. The issue of public sector performance or government performance has not a new one. The economic performance criterion (efficiency) is used to evaluate the performance of public expenditure and programs. However, the public sector is more complex than private sector due to natural differences between sectors ${ }^{26}$. Public sector performance analysis has become particularly important for governments and public policy makers with high public debt stock following the financial crises period. This public debt stock is a problem not only for current public budgets and current generations, but also for future public budgets and future generations. Therefore, performance should be evaluated effectively at all levels of the public sector ${ }^{27}$.

As stated before, determining public sector performance is very difficult due to the complex structure of the public sector. First of all, it is necessary to put forward the relationship between objectives, tools and results in a very good way to define public sector performance ${ }^{28}$. However, the goals in the public sector are multifaceted. Because the public sector has also non-economic obligations such as environmental and social benefits. On the other hand, because of the lack of advanced management information system in the public sector and data collection is not continuous, it is quite difficult to collect data with traditional performance evaluation methods ${ }^{29}$. Furthermore, not all performance indicators in the public sector are measurable.

\section{Literature}

There are several international studies addressing the issue of public sector productivity. In some of these studies, the productivity of the government is examined, and comparisons are made between countries. Some studies focus on sectors such as education, health and may be country-based or aim to examine cross-national trends. Some other studies aim to address the changes in productivity in public administration over time in individual countries ${ }^{30}$. In addition, due to the previously mentioned difficulties in measuring the efficiency of the public sector, performance evaluation based on the size of the public sector provides a more simple framework. Therefore, in the public finance

24 Mihaiu, D. (2014). Measuring Performance in the Public Sector: Between Necessity and Difficulty, Studies in Business and Economics, p.40-41.

25 Moreno-Enguix and Lorente Bayona, 2017, p.108.

26 Ömürgönülşen, U. (2002). Performance Measurement in the Public Sector: Rising Concern, Problems in Practice and Prospects, Hacettepe Üniversitesi, İktisadi ve İdari Bilimler Fakültesi Dergisi, 20(1), p.101.

27 Mihaiu, 2014, p.40.

28 Mihaiu, 2014, p.41.

29 Zhonghua, C., Ye, W. (2012). Research Frontiers in Public Sector Performance Measurement, Elsevier, Physics Procedia, 25, p.794.

30 Boyle, 2006, p.1-2. 
literature, it is a reasonable approach to evaluate the size of the state in terms of other economic and social indicators ${ }^{31}$. At the same time, most of the authors tend to use the share of total public expenditures in the GDP as a measure of the size of the public sector. Although this rate gives little information about the quality of outputs resulting from public expenditures, it is a very powerful tool in terms of revealing the performance of the government providing public goods and services ${ }^{32}$.

Gupta and Verhoeven ${ }^{33}$ examined the public expenditure efficiency on health and education expenditures in 85 countries for the period 1984-1995 using Free Disposal Hull (FDH) analysis. According to the findings obtained in the study, the effectiveness of public expenditures is higher in Asian countries than in African countries. They also found that as the increase in health and education expenditures raised, the efficiency of public expenditures decreased.

Afonso et al. ${ }^{34}$ investigated public sector performance in 24 countries for 2001 and 2003 with Data Envelopment Analysis and Tobit model estimation methods. They found out that public sector efficiency and performance are higher in countries where the ratio of public expenditures to GDP is less than $30 \%$. Besides, the security of property rights, per capita income, the proficiency of public servants, and people's education degrees positively affect public expenditure efficiency.

Boyle $e^{35}$ has discussed possible approaches to public sector efficiency measurement in public services in Ireland. In the study, three aspects of the effectiveness and performance of the public sector are examined, namely international comparative measurement, national and sectorial measurement and more micro level measurement. In this direction he has examined some of the key international initiatives in public sector efficiency measurement. Based on these developments, recommendations have been made to improve efficiency measurement in the Irish public sector. It was emphasized that the measurement of public sector efficiency should be improved, and more effort and resources should be devoted for this.

Mihaiu et al ${ }^{36}$ measured the public sector performance by using index estimation for the period 2000-2009 in European Union (EU) countries except for Malta. The public sector performance scores were highest in Luxembourg, Sweden, and Finland, while the lowest scores were in Poland, Romania, and Bulgaria.

Chan and Karim ${ }^{37}$ investigated the effectiveness of public expenditures for the period 2000-2007 in 8 East Asian countries with Data Envelopment Analysis and Tobit model estimation methods. The result which public expenditures are effective on economic performance, health, and education

31 Yaraşır Tülümce, S., Yavuz, E. (2018). Tanzi-Schuknecht Modellemesi Çerçevesinde Kamu Kesimi Performansının OECD Ülkeleri Açısından Analizi: Aras Yöntemi. Sosyal, Beşerî ve İdari Bilimlerde Akademik Araştırmalar-V, Edited by L. Aytemiz, E. Karayılmazlar, s.216.

32 Afonso, A. (2004). A Note on Public Spending Efficiency, Research Reports, CESifo DICE Report 1, p.35.

33 Gupta and Verhoeven, 2001.

34 Afonso et al., 2006.

35 Boyle, 2006.

36 Mihaiu et al., 2010.

37 Chan and Karim, 2012. 
in China was obtained from the study. However, public expenditures are less efficient due to the policies of solving income distribution inequality problem in East Asian countries. Lastly, it was found that improvements in financial freedom and political stability increased the effectiveness of public expenditures.

Zugravu and Sava ${ }^{38}$ analyzed the relationship between the performance and efficiency of the public sector in Romania for 2008 and 2011. The results obtained from the research indicate that public sector efficiency has decreased when public sector performance has increased.

Drucker and Geva ${ }^{39}$ examined the relationship between public sector expenditure and public sector output over 34 Organisation for Economic Co-operation and Development (OECD) countries for the period 2000-2010. In the study in which panel regression analysis was used as econometric method, it was found that public expenditures initially increased public sector performance and then decreased it. Accordingly, public sector performance reaches the highest level when the ratio of public expenditures in GDP is between 52\% and 60\%. According to another result obtained from the research, increases in public debt negatively affect public performance. Lastly, the researchers found that as the per capita income increased, public sector performance improved.

Mihaiu ${ }^{40}$ discussed the methods used in the measurement of performance in the public sector and disadvantages caused by these methods. Accordingly, the adverse effects of performance measurement in the public sector can take different forms but knowing them can contribute to the creation of an optimal system for performance management and measurement.

Leoveanu ${ }^{41}$ focused on the performance evaluation system and tools in the public sector and their implementation in Romania. In the study, it was concluded that public sector performance in Romania depends on the professionalism of civil servants in the public administration and reform should be made in the public sector in the line with the professional performance criterion.

Lovre et al. ${ }^{42}$ investigated the relationship between public expenditures and public sector performance for the period 2003-2013 in 19 developing countries. As a result of the analysis, the countries with high public sector sizes have higher public sector performance was determined. Besides, the highest public sector performance and efficiency take place in Scandinavian countries.

Moreno-Enguix and Bayona ${ }^{43}$ investigated the relationship between public sector size and performance in 2012 in 35 countries with the help of FDH and Ordinary Least Squares (OLS) analysis. According to the findings, the United States is one of the countries whose public sector is the least efficient. The countries with the highest public efficiency are Switzerland, Norway, and

38 Zugravu and Sava, 2012.

39 Drucker, L., Geva, A. (2013). What Drives Public Sector Performance?, Israel Economic Review, 10(2), p.43-69.

40 Mihaiu, 2014.

41 Leoveanu, 2016.

42 Lovre et al., 2017.

43 Moreno-Enguix et al., 2017. 
Korea. Another result obtained from the study is that a high level of democracy increases public efficiency.

Lobont et al. ${ }^{44}$ analyzed the public sector performance in the EU countries for the period 19952014 using basic component analysis. While GDP growth and GDP per capita make the biggest contribution to public sector performance among economic variables, inflation and unemployment are the second-largest contribution.

\section{Empirical Analysis and Results}

In this study, the effects of socio-economic variables on public expenditures, one of the most important indicators of public sector performance, for the period of 1990-2018 in Turkey were investigated. As socio economic variables, public borrowing, the unemployment rate, and human development index variables, which are widely used in the literature, are included in the model. The reason for choosing the 1990-2018 annual data as an example period is that the data of the public net debt stock variable started in 1990 and the HDI data ended in 2018.

\subsection{Data and Methodology}

Definitions and databases of the variables used in the study are shown in Table 1. The letter $L$ in front of the variables indicates the logarithmic form of the relevant variable.

Table 1: The Definitions and Databases of the Variables

\begin{tabular}{|c|c|c|}
\hline Variables & Definition & Database \\
\hline PE & Public Expenditures & $\begin{array}{c}\text { Republic of Turkey } \\
\text { Ministry of Treasury and Finance }\end{array}$ \\
\hline PD & $\begin{array}{c}\text { Public Net Debt Stock } \\
\text { (the share of GDP) }\end{array}$ & $\begin{array}{c}\text { Republic of Turkey } \\
\text { Ministry of Treasury and Finance }\end{array}$ \\
\hline UNE & Unemployment Rate & $\begin{array}{c}\text { TÜIK } \\
\text { (Turkish Statistical Institute) }\end{array}$ \\
\hline HDI & Human Development Index & $\begin{array}{c}\text { UNDP } \\
\text { (United Nations Development Programme) }\end{array}$ \\
\hline
\end{tabular}

\subsection{Descriptive Statistics}

Descriptive statistics of the variables used in the study are presented in the table below. Table 2 shows the means of the series, their highest and lowest values, standard deviations, skewness and kurtosis values.

44 Lobont, O. R., Moldovan, N. C., Bociu, A., Chis, C., Brîndescu Olariu, D. (2018). A Factor Analysis of the Public Sector Performance. Significant Differences, Economic Computation and Economic Cybernetics Studies and Research, 52 (2), p.139-156. 
Table 2: Descriptive Statistics of Variables

\begin{tabular}{|c|c|c|c|c|}
\hline Statistics & PE & PD & UNE & HDI \\
\hline Mean & 22.696 & 41.556 & 9.105 & 0.690 \\
\hline \multirow{2}{*}{ Maximum } & 33.543 & 72.599 & 12.552 & 0.807 \\
\hline & (2001) & (2001) & (2009) & (2018) \\
\hline \multirow{2}{*}{ Minimum } & 12.936 & 28.214 & 6.495 & 0.579 \\
\hline & $(1990)$ & $(2017)$ & $(2000)$ & $(1990)$ \\
\hline Std. Dev. & 4.878 & 11.395 & 1.539 & 0.075 \\
\hline Skewness & 0.336 & 1.134 & 0.111 & 0.143 \\
\hline Kurtosis & 3.154 & 3.812 & 2.272 & 1.731 \\
\hline Observations & 29 & 29 & 29 & 29 \\
\hline \multicolumn{5}{|c|}{$\begin{array}{l}\text { Note: The years in which the variables have their maximum and minimun } \\
\text { values are shown in parentheses. }\end{array}$} \\
\hline
\end{tabular}

As seen in Table 2, the variable with the highest standard deviation is the public debt stock variable. The large standard deviation of this variable indicates that public borrowing differs from year to year. The PD variable reached its highest value in 2001, the year of the crisis. Significant decline in GDP on the one hand and the requirement for large-scale borrowing on the other hand resulted in the highest PD value in 2001. Similarly, the mean of the public expenditure variable, which reached its maximum value in 2001, is $22.69 \%$. The highest value of the unemployment rate variable occurred in 2009 , another crisis year. Finally, the mean of HDI variable with the smallest standard deviation is 0.69 . The value of the index is between 0 and 1 , and it indicates the improvement in the human development index as it approaches 1 . The HDI variable, which takes its lowest and highest values in 1990 and 2018, respectively, has an increasing trend throughout the sample period.

\subsection{Unit Root Tests}

In time series analysis, it is very important to determine whether the variables contain unit roots or not ${ }^{45}$. Analyzes made with non-stationary series may lead to spurious regression problem. As stated by Granger and Newbold (1974) in the case of spurious regression, although the $\mathrm{R}^{2}$ value is high and the $t$ statistics of the coefficients are significant, the interpretation of the model will not be correct $^{46}$. For this reason, Augmented Dickey Fuller (ADF) and Phillips Perron (PP) tests, which are widely used in the literature and accepted as traditional unit root tests, were applied to the variables to determine whether they have unit root or not. The results obtained from the unit root tests are presented in Table 3.

45 Gujarati, D.N. (2003). Basic Econometrics, Fourth Edition, New York, McGraw-Hill, p.802.

46 Wooldridge, J. M. (2013). Introductory Econometrics: A Modern Approach, Fifth Edition, Mason, Cengage Learning, p.645. 
Table 3: The Results of Unit Root Tests

\begin{tabular}{|c|c|c|c|c|}
\hline \multirow{2}{*}{ Variables } & \multicolumn{2}{|c|}{ ADF } & \multicolumn{2}{c|}{ PP } \\
\cline { 2 - 5 } & Constant & Constant and Trend & Constant & Constant and Trend \\
\hline L.PE & $-2.527(2)$ & $-1.641(1)$ & -2.678 & -2.063 \\
\hline D.L.PE & $-4.703(0)^{\mathrm{a}}$ & $-4.863(0)^{\mathrm{a}}$ & $-4.703^{\mathrm{a}}$ & $-4.863^{\mathrm{a}}$ \\
\hline L.PD & $-1.809(0)$ & $-2.476(0)$ & -1.809 & -2.473 \\
\hline D.L.PD & $-5.960(0)^{\mathrm{a}}$ & $-3.483(0)^{\mathrm{c}}$ & $-5.955^{\mathrm{a}}$ & $-6.011^{\mathrm{a}}$ \\
\hline L.UNE & $-1.798(0)$ & $-3.221(1)$ & -1.702 & -2.055 \\
\hline D.L.UNE & $-4.403(0)^{\mathrm{a}}$ & $-4.325(0)^{\mathrm{a}}$ & $-4.339^{\mathrm{a}}$ & $-4.245^{\mathrm{a}}$ \\
\hline L.HDI & $-0.505(0)$ & $-4.427(5)^{\mathrm{a}}$ & -0.485 & -2.019 \\
\hline \multicolumn{7}{|c|}{ D.L.HDI } & $-2.983(6)^{\mathrm{a}}$ & $-3.879(0)^{\mathrm{b}}$ & $-3.934^{\mathrm{a}}$ & $-3.879^{\mathrm{b}}$ \\
\hline $\begin{array}{l}\text { Notes: The values in the table show the t-statistics obtained from the ADF test. a, b, and c denote the statistical significance } \\
\text { level at the 1\%, 5\%, and 10\% respectively. Number in the parenthesis is the optimal lag order for ADF test. D and L refer } \\
\text { the first difference and the logarithm form of the variable, respectively. }\end{array}$ \\
\hline
\end{tabular}

The results indicates that all series are non-stationary at the 5\% significant level, meaning that they are integrated at order one $[\mathrm{I}(1)]$. In the study, after determining the stationary levels of the series, cointegration analysis was applied to determine possible long run relationships among the variables.

\subsection{Cointegration Tests}

The notion of cointegration occurs when two series are I (1) and their linear combination is I (0). In this case, the two series move together is assumed that, in other words, there is a long-term relationship between them. The cointegration test, first applied by Engle-Granger (1987), was valid only for bivariate analysis. Later, thanks to the multivariate cointegration test developed by Johansen (1988), Johansen and Juselius (1990) and Johansen (1991), the long run relationships between more than two variables whose difference is stationary could be investigated ${ }^{47}$. Since all the variables are difference stationary, the long run relationship among them was analyzed with the help of the Johansen Multivariate Cointegration Test. The results of cointegration analysis are shown in Table 4.

Table 4: The Results of Johansen Multivariate Cointegration Test

\begin{tabular}{|c|c|c|c|c|c|c|c|}
\hline \multicolumn{2}{|c|}{ Hypothesis } & \multicolumn{2}{c|}{ Statistics } & \multicolumn{2}{c|}{ Critical Values (0.05) } & \multicolumn{2}{c|}{ Probability } \\
\hline $\mathrm{H}_{0}$ & $\mathrm{H}_{\AA}$ & Trace & Max-Eigen & Trace & Max-Eigen & Trace & Max-Eigen \\
\hline $\mathrm{r}=0$ & $\mathrm{r}=1$ & 51.027 & 24.986 & 47.856 & 27.584 & 0.024 & 0.103 \\
\hline $\mathrm{r} \leq 1$ & $\mathrm{r}=2$ & 26.041 & 17.179 & 29.797 & 21.131 & 0.124 & 0.163 \\
\hline
\end{tabular}

Notes: $\mathrm{r}$ denotes the number of cointegration vector. $\mathrm{H}_{0}$ and $\mathrm{H}_{\mathrm{A}}$ refer the null and alternative hypotheses, respectively.

Table 4 shows the results of the cointegration analysis between the variables. Both test statistics reject the null hypothesis of no cointegration rank at the $10 \%$ significance level. According to the results of cointegration analysis there is only one cointegration vector for Trace and Max-Eigen value statistics. 
Therefore, the results insisted that there is an equilibrium long run relationships among the variables. Long run coefficients obtained from the normalized vector are given in Table 5.

Table 5: Normalized Cointegrating Equation (Dependent Variable: L.PE)

\begin{tabular}{|c|c|c|c|}
\hline L.PE & L.PD & L.UNE & L.HDI \\
\hline \multirow{2}{*}{1.000} & -0.862 & 2.277 & -3.395 \\
& $(0.259)$ & $(0.379)$ & $(0.670)$ \\
\hline
\end{tabular}

Using the estimation results in the table, the cointegration equation will be formed as follows.

\section{L.PE=10.158+0.862 L.PD-2.277 L.UNE+3.395 L.HDI}

All of the long-term coefficients are statistically significant. According to the long run coefficients obtained, there are positive relationships from public borrowing and human development index to public expenditures. In other words, increases in the net public debt stock and human development index cause an increase in public expenditures. On the other hand, the long run coefficient of the unemployment rate variable is negative. Therefore, increases in the unemployment rate cause a decrease in public expenditures. Cointegration between two variables also provides information for the short run relationship and refers to a type of model called error correction model ${ }^{48}$. After determining the cointegration between the variables, the study covers error correction model. Estimated results of error correction model are show in Table 6.

Table 6: The Results of Vector Error Correction Model (VECM) Estimation (Dependent Variable: D.L.PE)

\begin{tabular}{|c|c|c|}
\hline Variables & Coefficient & t-statistic \\
\hline ECT(-1) & -0.180 & $-2.336^{\mathrm{a}}$ \\
\hline D.L.PD & -0.169 & -1.389 \\
\hline D.L.UNE & 0.100 & 0.478 \\
\hline D.L.HDI & -1.634 & -0.508 \\
\hline Constant & 0.026 & 0.624 \\
\hline \multicolumn{3}{|c|}{ Diagnostic Tests } \\
\hline $\mathrm{R}^{2}$ & \multicolumn{2}{|c|}{0.301} \\
\hline$\chi_{\mathrm{LM}}^{2}$ & \multicolumn{2}{|c|}{$5.322(0.993)$} \\
\hline$\chi_{\text {WHITE }}^{2}$ & \multicolumn{2}{|c|}{$94.725(0.630)$} \\
\hline \multicolumn{3}{|c|}{$\begin{array}{l}\text { Notes: a denotes the statistical significance level at the } 1 \% \text {. Number in the parenthesis is the p-value. } \\
\text { ECT(-1) refers the first lag of error correction term. }\end{array}$} \\
\hline
\end{tabular}


According to results of VECM, the lag of error correction term [ECT(-1)] is calculated negative and meaningful for statistical as expected. Thus, the obtained result supports the results of Johansen cointegration analysis. More clearly, the ECT (-1) value (0.180) indicates that nearly eighteen percent of the deviation from the current equilibrium disappears in the short run. At the same time these findings mean that there is an adjustment mechanism from short run to long run. On the other hand, short run coefficients obtained from the VECM estimate indicate different results compared to long run coefficients. All of the short run coefficients are statistically insignificant. According to the VECM results, there is no short-term relationship between the variables and government expenditures.

In econometrics, the correlation of dependent variables with error terms is referred to as an endogeneity problem. In the case of endogeneity problem, the independent variable can affect not only the dependent variable but also the error term ${ }^{49}$. The OLS estimator, developed by Phillips and Hansen (1990), re-predicts OLS without an endogeneity problem. Fully modified OLS estimator corrects for bias and endogeneity in the classic OLS estimator. Phillips and Hansen (1990) proved that the FMOLS estimator is super consistent, asymptotically unbiased, and asymptotically normally distributed. The authors assumed that the variables in the study were I (1) and cointegrated. Therefore, the FMOLS method can be applied to first order stationary variables that have a single cointegration relationship. In this respect, the FMOLS estimator allows both to confirm the cointegration relationship and to predict the relationship between variables more effectively. For this reason, the FMOLS method was applied in the study in order to both verify the results of the Johansen cointegration test and to compare the long run coefficients.

Table 7: The Results of FMOLS Estimation (Dependent Variable: L.PE)

\begin{tabular}{|l|c|c|}
\hline Variables & Coefficient & t-statistic \\
\hline L.PD & 0.881 & $6.151^{\mathrm{a}}$ \\
\hline L.UNE & -0.626 & $-2.792^{\mathrm{a}}$ \\
\hline L.HDI & 2.330 & $5.501^{\mathrm{a}}$ \\
\hline Constant & 6.143 & $8.943^{\mathrm{a}}$ \\
\hline $\begin{array}{l}\mathrm{R}^{2}=0.555 \\
\text { F-statistic: } 14.649(0.000)\end{array}$ \\
\hline $\begin{array}{l}\text { Notes: a denotes the statistical significance level at the } 1 \% \text {. Number in the parenthesis is the } \\
\text { p-value. }\end{array}$
\end{tabular}

Table 7 gives the estimation results of FMOLS. The results obtained both confirm the existence of cointegration revealed by the Johansen cointegration test and are match up with the signs of longrun coefficients. According to FMOLS findings, L.PD and L.HDI variables have positive impacts on L.PE, whereas L.UNE variable has negative impact on L.PE. As a result of the analysis, the coefficient of the public debt stock variable was found to be positive and statistically significant. Accordingly, an increase of $1 \%$ in public borrowing causes an increase of $0.88 \%$ in public expenditures. Similarly, 
the coefficient for the HDI variable is also positive and statistically significant. This result suggests that a one percent increase in the L.HDI increase the L.PE nearly $2.33 \%$. Finally, the coefficient of the L.UNE variable was found to be statistically significant and negative, as in the Johansen cointegration analysis. This result indicates that a $1 \%$ increase in the unemployment rate will lead to a $0.62 \%$ decrease in public expenditures. To sum up the results of FMOLS, increases in public borrowing and human development index lead to an increase in public expenditures, while increases in the unemployment rate cause a decrease in public expenditures.

\section{Conclusion and Discussion}

Nowadays, in addition to the size of the public sector and the role of the public sector in economic and social life, the issue of performance in the public sector also has a special importance. In other words, issues such as how the government will fulfill its functions, what is the most effective way of providing public services, how much it will spend and how it will ensure efficiency are important. In fact, the issue of public sector performance is not new. Efficiency criteria are used in evaluating the performance of public institutions, services and programs. However, since the nature of the public sector and the goods and services offered by the public sector is very different from the private sector, it is very difficult for the public sector to evaluate the efficiency criterion.

It is widely accepted in the public finance literature that the share of public expenditures in GDP is used as a tool to measure the size of the public sector. It is also known that the size of public expenditures has an important role in ensuring the efficiency and performance of the government. In this regard, the ratio of public expenditures to GDP can be considered as one of the most important determinants of public sector performance.

In this study, unlike other studies in the literature, the effect of socio-economic variables on public expenditures was investigated. On the other hand, one of the most important indicators of the size of the public sector is the share of public expenditures in the GDP. Thus, the study tried to analyze the effects of different socio-economic factors on public performance through public expenditures.

As a result of the cointegration analysis used the annual data from 1990 to 2018, it has been determined that the variables are cointegrated. According to the long run coefficients obtained, public net debt stock and human development index variables have a positive effect on the public expenditure variable. Accordingly, public expenditures increase as public borrowing increases. $1 \%$ increase in public debt stock increases public expenditures by nearly $0.8 \%$. In other words, public borrowing contributes to the financing of public expenditures in the long run. Similarly, there is a positive long run relationship between the human development index, which includes factors such as health, education and income, and public expenditures. Rises in health, education, and income increase the human development index value, too. Higher education, health, and income levels create a better and higher quality public service expectation in individuals. Therefore, rises in HDI exert upward pressure on public expenditures, causing an increase in public expenditures. Besides, the rise in HDI can increase the quality of human capital and make a positive contribution to the 
increase in production and income. This situation can allow more resources to be allocated to public expenditures, especially through the increase in tax revenues.

The long run effect of the unemployment rate, which is another variable used in the study, on public expenditures was determined negatively. In other words, increases in the unemployment rate lead to a decrease in public expenditures. The increase in the unemployment rate may cause a decrease in the social security contributions earned by the public through employment, and a decrease in production and tax revenues. Thus, the resources allocated to public expenditures also shrink and a decrease may occur in public expenditures. Resources, such as social assistance and unemployment insurance for unemployed people in Turkey are not creating too much size in public expenditures ${ }^{50}$. Therefore, rises in unemployment rates cannot create upward pressure on public expenditures. As a result, in this study, it has been determined that socio-economic variables such as public debt stock, education expenditures, health expenditures, unemployment rate, etc. affect public sector performance by changing public expenditures.

\section{References}

AFONSO, A. (2004). A Note on Public Spending Efficiency, Research Reports, CESifo DICE Report 1: 35-39.

AFONSO, A., Schuknecht, L., Tanzi, V. (2006). Public Sector Efficiency: Evidence for New EU Member States and Emerging Markets, ECB Working Paper, 581.

AFONSO, A., Romero, A., Monsalve, A. (2013). Public Sector Efficiency: Evidence for Latin America, InterAmerican Development Bank, Discussion Paper, 279.

ALLEN, R., Tommasi, D. (2001). Managing Public Expenditure: A Reference Book for Transition Countries, http://www1.worldbank.org/publicsector/pe/oecdpemhand book.pdf, (Accessed On: 05.07.2019).

BOYLE, R. (2006). Measuring Public Sector Productivity: Lesson from International Experience, CPMR Discussion Paper, 35.

CHAN, S., Karim, M. Z. A. (2012). Public Spending Efficiency and Political and Economic Factors: Evidence from Selected East Asian Countries, Economic Annals, LVII, 193: 7-23.

CIMA (2011). Public Sector Performance: A Global Perspective, https://www.cimaglobal.com/Documents/ Thought_leadership_docs/NHS-public sector/ public_sector_report_web_oct_2011.pdf, (Accessed On:07.05.2019).

DICKEY, D. A., Fuller, W. A. (1979). Distribution of the Estimators for Autoregressive Time-Series With a Unit Root, Journal of the American Statistical Association, 74(366): 427-431.

DRUCKER, L., Geva, A. (2013). What Drives Public Sector Performance?, Israel Economic Review, 10(2), 43-69.

ENGLE, R. F., and Granger, C. W. J. (1987). Cointegration and Error Correction: Representation, Estimation, and Testing, Econometrica: 55, 251-276.

GRANGER, C. W. J., and Newbold, P. (1974). Spurious Regressions in Econometrics, Journal of Econometrics, 2: $111-120$.

GUJARATI, D. M. (2003), Basic Econometrics, Fourth Edition, New York, McGraw-Hill.

GUPTA, S., Verhoeven, M. (2001). The Efficiency of Government Expenditure Experiences from Africa, Journal of Policy Modeling, 23: 433-467.

50 For example, according to the data obtained from The Ministry of Treasury and Finance and the Turkish Employment Agency, the ratio of unemployment insurance payments to public expenditures was only $0.007 \%$ in 2019 . 
GÜRAN, M. C., Cingi, S. (2002). Devletin Ekonomik Müdahalelerinin Etkinliği, Akdeniz İ.İ.B.F. Dergisi, 3: 5689.

JOHANSEN, S. (1988). Statistical analysis of cointegration vectors, Journal of Economic Dynamics and Control, 12: 231-234.

JOHANSEN, S. (1991). Estimation and Hypothesis Testing of Cointegrated Vectors in Gaussian Vector Autoregressive Models, Econometrica, 59(6): 1551-1580.

JOHANSEN, S., Juselius, K. (1990). Maximum Likelihood Estimation and Inferences on Cointegration With Applications to the Demand for Money, Oxford Bulletin of Economics and Statistics, 52(2): 169-210.

LEOVEANU, A. (2016). Performance Evaluation Systems in the Public Sector, Curentul Juridic, 26-38.

LOBONT, O. R., Moldovan, N. C., Bociu, A., Chis, C., Brîndescu Olariu, D. (2018). A Factor Analysis of the Public Sector Performance, Significant Differences between Old and New EU Countries, Economic Computation and Economic Cybernetics Studies and Research, 52 (2): 139-156.

LOVRE, I., Ivanović, O. M., Mitić, P. (2017). Analysis of Public Sector Efficiency in Developed Countries, Economic Analysis, 50(1-2): 38-49.

LUCAS, R. E. (1988). On the Mechanics of Economic Development, Journal of Monetary Economics, 22: 3-42.

MIHAIU, D. M., Opreana, A., Cristescu, M. P. (2010). Efficiency, Effectiveness and Performance of the Public Sector, Romanian Journal of Economic Forecasting, 4: 132-147.

MIHAIU, D. (2014). Measuring Performance in the Public Sector: Between Necessity and Difficulty, Studies in Business and Economics, 40-50.

MORENO-ENGUIX, M. R., Lorente Bayona, L. V. (2017). Factors Affecting Public Expenditure Efficiency in Developed Countries, Politics \& Policy, 105-143.

ÖMÜRGÖNÜLŞEN, U. (2002). Performance Measurement in the Public Sector: Rising Concern, Problems in Practice and Prospects, Hacettepe Üniversitesi, İktisadi ve İdari Bilimler Fakültesi Dergisi, 20(1): 99134.

PHILLIPS, P.C.B., and Hansen, B.E. (1990). Statistical inference in instrumental variable regression with I (1) processes, Review of Economic Studies, 57: 99-125.

PHILLIPS, P. C. B., Perron, P. (1988). Testing for a Unit Root in Time-Series Regression, Biometrika, 75(2): 334-346.

PREMCHAND, A. (1996). Issues and New Directions in Public Expenditure Management, IMF Working Paper, 123.

SAKAL, M., Şahin, E. A. (2008). Kamu Kurumlarında Performans Ölçümü ve Sayıştay Denetimi İlişkisi: Türkiye’deki Düzenlemeler Bakımından Bir Değerlendirme, Sayıştay Dergisi, 68: 3-27.

SCHWAB, K. (2013). Global Competitivenes Report 2013-2014, World Economic Forum, http://www3. weforum.org/docs/WEF_GlobalCompetitivenessReport_2013-14.pdf, (Accessed On: 05.07.2019).

TANZI, V., Afonso, A., Schuknect, L., Veldhuis, N. (2007). Public Sector Efficiency: An International Comparison, The Fraser Institute, https://www.fraserinstitute.org/sites/ default/files/PublicSectorEfficiency.pdf, (Accessed On:12.06.2019).

WOOLDRIDGE, J. M. (2003). Introductory Econometrics: A Modern Approach, Fifth Edition, Mason, Cengage Learning.

YARAŞIR TÜLÜMCE, S., Yavuz, E. (2018). Tanzi-Schuknecht Modellemesi Çerçevesinde Kamu Kesimi Performansının OECD Ülkeleri Açısından Analizi: Aras Yöntemi. Sosyal, Beşerî ve İdari Bilimlerde Akademik Araştırmalar-V, Edited by L. Aytemiz, E. Karayılmazlar, Ankara.

YENİCE, E. (2006). Kamu Kesiminde Performans Ölçümü ve Bütçe İlişkisi, Sayıştay Dergisi, 61: 57-68.

ZAGLER, M., Dürnecker, G. (2003). Fiscal Policy and Economic Growth, Journal of Economic Survey, 17: 397-418. 
ZHONGHUA, C., Ye, W. (2012). Research Frontiers in Public Sector Performance Measurement, Elsevier, Physics Procedia, 25: 793-799.

ZUGRAVU, B. G., Sava, A. Ş. (2012). Recent Changes in Public Sector Efficiency in Romania: Determinants and Implications, Elsevier, Procedia-Social and Behavioral Sciences, 58: 423-433.

5018 Sayılı Kamu Mali Yönetimi ve Kontrol Kanunu. 
As a result of the developments in the field of globalization and information and communication technologies, a number of changes and transformations have been experienced in the field of public administration, as in many other fields. Thus, a new public management understanding has been adopted in order to provide faster, more effective and efficient service in the public sector. With this understanding, the concept of performance has gained importance in the public sector, and benefits and results arising from the transaction have started to be considered as the main element. Undoubtedly, the main function of the state is to produce public goods and services and to provide the necessary financing for this. Therefore, the issues of how much to spend for public goods and services and how to ensure efficiency while spending are important for governments.

Governments in many countries are trying to improve the performance of the public sector. However, the lack of a clearly defined output in the public sector and the fact that the public sector differs from the private sector in many ways makes it difficult to evaluate the effectiveness of the public policies implemented. The main problem here stems from the fact that the main purpose in the public sector is to increase the social benefit, that is, the welfare level of the society, and therefore, concrete data reflecting profit in the public sector similar to the private sector cannot be obtained. In addition, the dimension of the public sector in the economy, the political, administrative and institutional structure of the country, the size and structure of the population have an impact on the size of the public sector and thus on the performance of the public sector, which makes this measurement difficult.

Ultimately, public sector performance reveals the impact of state activities on some basic economic and social indicators and shows the outcome of public sector activities. In general, the share of total public expenditures in GDP is used as a measure of the size of the public sector in the literature. Although this ratio gives little information about the efficiency of outputs arising from public expenditures, it is considered as a very powerful tool in terms of demonstrating the performance of the government providing public goods and services. As a matter of fact, due to the problems mentioned earlier in determining the effectiveness of the public sector, the approach of evaluating the performance based on the size of the public sector is common in the literature.

In the literature, generally, the effects of public expenditures on socio-economic variables such as education expenditures, health expenditures, unemployment rate, and public borrowing, etc. have been investigated. In most of these studies, as public expenditures increased, the socio-economic variables improved was concluded that. In this study, unlike other studies in the literature, the effect of socio-economic variables on public expenditures was investigated. On the other hand, one of the most important indicators of the size of the public sector is the share of public expenditures in the GDP. Thus, the study tried to analyze the effects of different socio-economic factors on public performance through public expenditures.

As a result of the cointegration analysis used the annual data from 1980 to 2018, it has been determined that the variables are cointegrated. According to the long run coefficients obtained, public net debt stock and human development index variables have a positive effect on the public 
expenditure variable. Accordingly, public expenditures increase as public borrowing increases. $1 \%$ increase in public debt stock increases public expenditures by nearly $0.8 \%$. In other words, public borrowing contributes to the financing of public expenditures in the long run. Similarly, there is a positive long run relationship between the human development index, which includes factors such as health, education and income, and public expenditures. Rises in health, education, and income increase the human development index value, too. Higher education, health, and income levels create a better and higher quality public service expectation in individuals. Therefore, rises in HDI exert upward pressure on public expenditures, causing an increase in public expenditures. Besides, the rise in HDI can increase the quality of human capital and make a positive contribution to the increase in production and income. This situation can allow more resources to be allocated to public expenditures, especially through the increase in tax revenues.

The long run effect of the unemployment rate, which is another variable used in the study, on public expenditures was determined negatively. In other words, increases in the unemployment rate lead to a decrease in public expenditures. The increase in the unemployment rate may cause a decrease in the social security contributions earned by the public through employment, and a decrease in production and tax revenues. Thus, the resources allocated to public expenditures also shrink and a decrease may occur in public expenditures. Resources, such as social assistance and unemployment insurance for unemployed people in Turkey are not creating too much size in public expenditures. Therefore, rises in unemployment rates cannot create upward pressure on public expenditures. As a result, in this study, it has been determined that socio-economic variables such as public debt stock, education expenditures, health expenditures, unemployment rate, etc. affect public sector performance by changing public expenditures. 